\title{
Darwin's Earthquake
}

\author{
RICHARD V. LEE, M.D.
}

\begin{abstract}
Charles Darwin experienced a major earthquake in the Concepcion-Valdivia region of Chile 175 years ago, in February 1835. His observations dramatically illustrated the geologic principles of James Hutton and Charles Lyell which maintained that the surface of the earth was subject to alterations by natural events, such as earthquakes, volcanoes, and the erosive action of wind and water, operating over very long periods of time. Changes in the land created new environments and fostered adaptations in life forms that could lead to the formation of new species. Without the demonstration of the accumulation of multiple crustal events over time in Chile, the biologic implications of the specific species of birds and tortoises found in the Galapagos Islands and the formulation of the concept of natural selection might have remained dormant.
\end{abstract}

(Rev Med Chile 2010; 138: 897-901).

Key words: Adaptation, biological; Earthquakes; Evolution; History, modern; Natural history.

\section{El terremoto de Darwin}

Hace 175 años (febrero de 1835) Charles Darwin presenció un gran terremoto en Concepción y Valdivia, en Chile. Sus observaciones ilustraron dramáticamente los principios geológicos de James Hutton y Charles Lyell, quienes sostenían que la superficie de la tierra estaba expuesta a alteraciones por eventos naturales, tales como terremotos, erupciones volcánicas y la acción erosiva del viento y el agua, operando durante largos períodos de tiempo. Cambios en la tierra crearon nuevos ambientes y fomentaron adaptaciones en las formas de vida que pudieron conducir a la formación de nuevas especies. Sin la demostración de múltiples eventos acumulados en la corteza terrestre a través del tiempo, en Chile, las implicaciones biológicas de las especies de aves y tortugas descubiertas en las Islas Galápagos y la formulación del concepto de selección natural habrían permanecido latentes.

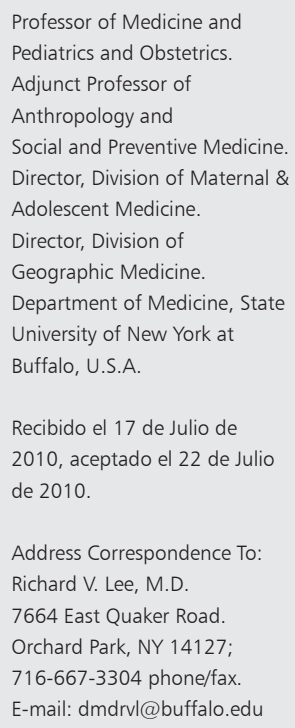

T he first half of the year 2010 was punctuated by major earthquakes: two in the Western Hemisphere-Haiti and Chile. The human suffering, deaths, and destruction of the natural and constructed environments have dominated the media and propelled relief and reconstruction efforts from around the globe. The intensity of despair and the urgency of response concentrated action and reflection with such immediacy that the history of the natural history and science of earthquakes, as well as the development of our understanding of the planet's structure and operation, may be submerged and forgotten.

One hundred and seventy five years ago (February 20,1835) a major earthquake, in the same region of Chile as the earthquake of 2010, played a substantial role in the shaping of modern biology and earth science. The temblor was experienced by Charles Darwin, Captain Robert FitzRoy, and the crew of the Beagle during their stay at Valdivia and 
Concepción in February and March, 1835. Both Darwin and FitzRoy recorded their observations in their journals.

Darwin's Journal of Researches ${ }^{1}$, published in 1839, documents the importance of the Concepción earthquake in shaping his thinking about the age and transformation of the earth. Thinking that became a crucial component in the concept of evolution. The notion that the earth was only 6,000 and some years old was one of the pillars of the dogma that the planet and its life forms were created by the God of Jews and Christians. Darwin became fascinated with geology under the tutelage of Adam Sedgwick, Professor of Geology at Cambridge, whom he accompanied on a field trip to Wales during the summer of 1831 before he signed on to accompany Captain FitzRoy on the Beagle. During that last year of his Cambridge education Charles Lyell's first volume of his grand discourse on geology was published which gave precedence to the work of James Hutton and the Scottish geologists and natural historians ${ }^{1}$. The special status of the created earth was questioned by the Scots in the last quarter of the $18^{\text {th }}$ century beginning with observations and reports by James Hutton in $1788^{3}$. Hutton read his paper, Concerning the System of the Earth, at a meeting of the Royal Society of Edinburgh, on July 4, 1785, in which he set forth the basic themes of what was to become labeled "uniformitarianism":

"The solid parts of the present land appear in general, to have been composed of the productions of the sea, and of other materials similar to those now found upon the shores. Hence we find reason to conclude:

$1^{\text {st }}$, That the land on which we rest is not simple and original, but that it is a composition, and had been formed by the operation of second causes.

$2^{\text {nd }}$, That before the present land was made, there had subsisted a world composed of sea and land, in which were tides and currents, with such operations at the bottom of the sea as now take place. And,

Lastly, That while the present land was forming at the bottom of the ocean, the former land maintained plants and animals; at least the sea was then inhabited by animals, in a similar manner as it is at present.

Hence we are led to conclude, that the greater part of our land, if not the whole had been produced by operations natural to this globe; but that in order to make this land a permanent body, resisting the operations of the waters, two things had been required;

$1^{\text {st }}$, The consolidation of masses formed by collections of loose or incoherent materials;

$2 n d l y$, The elevation of those consolidated masses from the bottom of the sea, the place where they were collected, to the stations in which they now remain above the level of the ocean."

These observations and principles were supported by John Playfair and Sir James Hall, geological colleagues of Hutton, and elaborated extensively by Charles Lyell. Lyell's monumental three volume work was published between 1830 and 1833. Darwin was given a copy of the first volume by Captain FitzRoy and was sent a copy of the second volume by his family while he was in South America. In 1835 Darwin's perception of the history of the earth and its living creatures, influenced by Charles Lyell's Principles of Geology, which exposed the inaccuracies of traditional Biblical geologic teaching, was already in flux.

Darwin had completed his various passages across the Cordillera of the Andes from Argentina to Chile and had rejoined the Beagle at Valdivia several days before the earthquake. During the preceding two years the fossils and new species Darwin found in Brazil and Argentina and the marine shells that were present in places distant from the sea raised doubts about the stability of species and the surface of the planet. Darwin was on shore February $20^{\text {th }}$.*

"I happened to be on shore, and was lying down in the wood to rest myself. It came on suddenly, and lasted two minutes; but the time appeared much longer. The rocking of the ground was most sensible. The undulations appeared to my companion and myself to come from due east; whilst others thought they proceeded from south-west; which shows how difficult it is in all cases to perceive the direction of these vibrations. There was no difficulty in standing upright, but the motion made me almost giddy. It was something like the movement of a vessel in a little cross ripple, or still more like that felt by a person skating over thin ice, which bends under the weight of his body.

\footnotetext{
*All of the quotations are from pages 368-381 in the Journal of Researches.
} 
Captain Fitz Roy and the officers were at the town during the shock, and there the scene was more awful; for although the houses, from being built of wood, did not fall, yet they were so violently shaken that the boards creaked and rattled. The people rushed out of doors in the greatest alarm."

The Beagle left Valdivia on February $22^{\text {nd }}$ and reached Concepción on March $4^{\text {th }}$. Darwin was landed on the barrier island of Quiriquina to assess the devastation. He was told:

"that not a house in Concepcion, or Talcuhano, (the port) was standing; that seventy villages were destroyed; and that a great wave had almost washed away the ruins of Talcuhano." Of this latter fact I soon saw abundant proof; the whole coast being stewed over with timber and furniture, as if a thousand great ships had been wrecked... The storehouses at Talcuhano had burst open, and great bags of cotton, yerba, and other valuable merchandise, were scattered about on the shore."

When he arrived at Talcahuano port and Concepción the next day he learned that the destruction was the product of both movement of land and movement of the sea, the tsunami.

"The earthquake (in Concepcion) commenced at half-past eleven in the forenoon. If it had happened in the middle of the night the greater number of the inhabitants (which in this one province amount to many thousands), instead of less than a hundred, must have perished. In Concepcion, each house, or row of houses, stood by itself, a heap or line of ruins; but in Talcuhano, owing to the great wave, little more than one layer of bricks, tiles, and timber, with here and there part of a wall left standing, could be distinguished.

Captain FitzRoy has given an account of the great wave, which, traveling from seaward, burst over Talcuhano. In the middle of the bay it was seen as one unbroken swell of the water; but on each side, meeting with resistance, it curled over, and tore up cottages and trees as it swept onwards with overwhelming force.

The great wave, however, was far more destructive in this respect: on one low island near the head of the bay, seventy animals were washed off and drowned. It is generally thought that this has been the worse earthquake ever recorded in Chile; but as the very bad ones occur only after long intervals, this cannot easily be known; ...

In almost every severe earthquake which has been described, the neighbouring waters of the sea are said to have been greatly agitated. The disturbance seems generally, as in the case of Concepcion, to have been of two kinds: first, at the instant of the shock, the water swells high up on the beach, with a gentle motion, and then as quietly retreats; secondly, some little time afterwards, the whole body of the sea retires from the coast, and then returns in great waves of overwhelming force.

In reading accounts of earthquakes, and especially of those on the west coast of America, as collated from various authors by Sir W. Parish, it is certain that the first great movement of the waters has been that of retiring.

Considering then a wave produced by an earthquake as an ordinary undulation proceeding from some point or line in the offing, we can see the cause, first of its occurrence some time after the shock; secondly, of its affecting the shores of the mainland and of outlying islets in a uniform manner-namely, the water retiring first, and then returning in a mountainous breaker; and lastly, of its size being modified (as appears to be the case) by the form of the neighbouring coast."

The Beagle remained in Concepción long enough to observe and record the other consequences of the temblor and tsunami; namely, alterations in the changes in elevation and shape of the land.

"The most remarkable effect (or perhaps speaking more correctly, cause) of this earthquake was the permanent elevation of the land.

The phenomenon possesses an uncommon degree of interest, from this particular part of the coast of Chile having previously been the theatre of several earthquakes of the worst class. It is almost certain, from the altered soundings, together with the circumstance of the bottom of the bay near Penco, consistent of hard stone, that there has been an uplifting to the amount of four fathoms, since the famous convulsion of 1751. With this additional instance fresh before us, we may assume as probably, according to the principles of Mr. Lyell, other small successive elevations,...

The elevation of the land to the amount of some feet during these earthquakes, appears to be a pa- 
roxysmal movement, in a series of lesser and even insensible steps, by which the whole west coast of South America has been raised above the level of the sea."

The connection between the crustal shifts and fractures and the formation of volcanoes was demonstrated and dramatized by a series of volcanic eruptions along the Andean fault lines following the 1835 earthquake.

"In this instance, however, at the same hour when the whole country around Concepcion was permanently elevated, a train of volcanoes situated in the Andes, in front of Chiloe, instantaneously spouted out a dark column of smoke, and during the subsequent year continued in uncommon activity. It is, moreover, a very interesting circumstance, that, in the immediate neighbourhood, these eruptions entirely relieved the trembling ground, although at a little distance, and in sight of the volcanoes, the island of Chiloe was strongly affected. To the northward, a volcano burst out at the bottom of the sea adjoining the island of Juan Fernandez, and several of the great chimneys in the Cordillera of central Chile commenced a fresh period of activity. We thus see a permanent elevation of the land, renewed activity through habitual vents, and a submarine outburst, forming parts of one great phenomenon."

Volcanoes and volcanism were to continue as a fundamental theme when the Beagle reached the Galapagos Islands. There Darwin could observe the flora and fauna of a cluster of volcanic islands, differing in ages and habitats. The differences in avian, reptilian, and plant life among the Islands became important facts in the formation of the concept of natural selection during the decade following his return to England in 1836 as Darwin studied the specimens collected by the Beagle.

It is clear from Darwin's Journal that he appreciated the possibility that the structure of the earth's surface was a layer of solids floating on a liquid; a pre-tectonic plate hypothesis for the origins of earthquakes and volcanoes.

"A bad earthquake at once destroys the oldest associations: the world, the very emblem of all that is solid, has moved beneath our feet like a crust over a fluid; -one second of time has conveyed to the mind a strange idea of insecurity, which hours of reflection would never have created."
He also had a sense of future risks to the seemingly secure and settled countries like England: a premonition fulfilled in the ensuing two centuries.

"Earthquakes alone are sufficient to destroy the prosperity of any country. If, for instance, beneath England, the now inert subterranean forces should exert those powers which most assuredly in former geological ages they have exerted, how completely would the entire condition of the country be changed! What would become of the lofty houses, thickly-packed cities, great manufacturies, the beautiful public and private edifices? If the new period of disturbance were first to commence by some great earthquake in the dead of the night, how terrific would be the carnage! England would at once be bankrupt; all papers, records, and accounts would from that moment be lost. Government being unable to collect the taxes, and failing to maintain its authority, the hand of violence and rapine would go uncontrolled. In every large town famine would be proclaimed, pestilence and death following in its train."

For historians of biology and science perhaps the most important observation by the young naturalist was Darwin's recognition that the face of the earth could be rapidly altered by natural as opposed to supernatural events.

"It is a bitter and humiliating thing to see works, which have cost men so much time and labour, overthrown in one minute; yet compassion for the inhabitants is almost instantly forgotten, from the interest excited in finding that state of things produced in a moment of time, which one is accustomed to attribute to a succession of ages".

The dilemma Darwin had to cope with had to do with the biblical interpretation of the earth's history, which held that the earth was a special creation as were the living creatures that inhabited its waters and lands. Changes in the landscape were produced by supernatural events such as the flood that forced Noah to construct and populate the Ark. Species also could not change without the action of God. For Darwin, observing the diversity of life that burgeoned in the newly explored regions of South America, Australia, and the islands of the great oceans, the fossils and profusion of life forms indicated the transformation of existing species 
into new varieties. Just as the accumulation of geologic events could explain the geographic and geologic findings of the Andes mountains and the Pacific coastline of South America, so could the accumulation of biologic events explain flamboyant diversity. Both processes need eons of time.

The concept of a static world meant that species were permanent and did not change, so that the identification of new species during the voyages of discovery during the $18^{\text {th }}$ and early $19^{\text {th }}$ centuries was considered evidence of separate creations previously unrecognized. If the formation of the earth and its life forms were the product of God's creation, when God decided, then an abbreviated earth history was all that was needed to explain the diversity of the geographic, geologic, and biologic environment. The dogma that the earth was created and then reshaped by God through events such as the great flood that required Noah to rescue the original species of the created earth was used to explain the all-too-obvious evidence of recent changes in the surface and landscape of the planet. The supposition of repeated instances of supernatural events to explain the geologic and biological discoveries identified by explorernaturalists kept at bay the synthesizing of ideas by students of geology and natural history. As long as the planet was young and unchangeable, except by God, the possibility of evolution was not only undesirable but impossible.

In the years following the return from the Beagle voyage Darwin studied Lyell's books and utilized Lyell's concepts in organizing and developing an explanation of the adaptation of life forms to changing environs. Lyell became a close friend and mentor for Darwin but remained something of a skeptic for the concept of evolution. It took Darwin's study of Thomas Malthus on the population limits of the earth, which he read after his return, to complete the construction of the foundations of the notion of "natural selection."

It is easy to lose sight of the importance of geologic theory and observation to the formulation of the origin of species by natural selection. Young Darwin considered himself something of a geologist. Darwin was an active member of the Geological Society of London, became the secretary to the Society, and gave one of his early post
Beagle papers to the Geological Society which was published in the 1837-1838 volume of the Transactions of the Society ${ }^{4}$.

"Uniformitarianism" was essential for the formulation of natural selection. As the concept of natural selection took shape in the writings of Darwin, Wallace, Huxley, Spencer, and others, an older, unstable, and changeable planet became necessary in order to allow time for ecological change and biological adaptations to occur. Indeed, the age of the earth continues to be a focus of contention for opponents of evolution and evolutionary science.

Darwin witnessed volcanic eruptions on the island of Chiloé in 1834 and the earthquake at Concepción in 1835. Without these dramatic and destructive events his understanding of the earth's age and the processes of change would have depended upon the observations and reports of other scientists and perhaps would have been delayed. Chile, not the Galapagos, provided the demonstration of how the surface of the earth could be altered; experiences that Alfred Russel Wallace, Darwin's compatriot in describing the process of natural selection, did not share.

The tragedies of earthquakes, tsunamis, and volcanic eruptions have their hidden lessons and value for those that are able to use them to increase and improve human understanding. I expect that thoughtful and visionary observers of the earthquakes of 2010 will do the same.

\section{References}

1. Darwin, Charles. Journal of Researches into the Geology and Natural History of the Varius Countries Visited by the HMS Beagle Under the Command of Captain Fitzroy, RN, from 1832 to 1836, Henry Colburn, London, 1839.

2. Lyell, Charles. Principles of Geology, Vol. 1-3, J. Murray, London, 1830-1833.

3. Hutton, James. Theory of the Earth; or an Investigation of the Laws Observable in the Composition, Dissolution, and Restoration of Land Upon the Globe. Transactions of the Royal Society of Edinburgh, 1788.

4. Darwin, Charles. On the Formation of Mould. Proceedings of the Geological Society of London, Vol. II, 1837 and 1838 , pp. 574-576. 